\title{
Reflections on Fanon's legacy
}

\section{David Austin, Aziz Choudry, Radha D'Souza, Sunera Thobani}

Many people consider Martinique-born Frantz Fanon to be one of the most important anti-colonial thinkers of the twentieth century. Aziz Choudry, one of the co-editors of this issue of Interface, initiated a discussion with three colleagues - David Austin, Radha D'Souza, and Sunera Thobani - after many conversations about the legacy of Fanon in the course of collaborations in both academic and activist milieus. These four short pieces discuss the relevance of Fanon's writings for thought and action in struggles today. In doing so, they draw upon the writers' personal, political, activist and academic engagements with Fanon's writings and the questions which he grappled with, in a life cut short by leukemia at the age of 35 in December 1961.

\section{David Austin}

\section{When did you first encounter Fanon, in what context, and how did it impact you?}

I first encountered Fanon as a high school student in Toronto. As a youth I spent a lot of time at Third World Bookstore in Toronto. Many of us as young women and men would go there on the weekends or whenever we had free time to buy books, but more importantly to discuss, debate, and exchange ideas on a range of subjects, local and international, and especially on issues related to people of African descent. I must admit that I did not understand everything that I read in Fanon's Black Skin, White Masks, but what I did understand really shaped my consciousness. The idea of being Black, but wearing a white mask spoke to me. It explained how we had been shaped by the dominant culture, dominant ideologies, and the deep-seated psychological impact of colonization and racism on the Black psyche. Fanon's writing was a revelation in that sense and provided a language that helped me to understand how race operated, how it is etched in the consciousness - of both the colonized and the colonizer.

\section{Violence}

The Wretched of the Earth was another matter. When Fanon spoke about violence in the colonial setting, it resonated with me because it helped to explain the fratricidal violence that I saw around me among Black youth. It explained that oppression and colonization was crucial in terms of understanding the 
Interface: a journal for and about social movements Volume 5 (1): 128 - 150 (May 2013)
Article

Austin, Choudry, D’Souza, Thobani, Reflections on Fanon

social, economic, and political circumstances that produced violent phenomenon.

The popular assumption was, and remains, that Blacks are somehow predisposed to violence, almost as if it is embedded in DNA. Fanon's analysis of violence provided a context, a sociological explanation as to why violence occurs; how forms of oppression create pent-up anger and frustration resulting in internalized oppression as the oppressed or colonized feel incapable of challenging colonialism or oppression:

\begin{abstract}
While the settler or the policeman has the right the livelong day to strike the native, to insult him and to make him crawl to them, you will see the native reaching for his knife at the slightest hostile or aggressive glance cast on him by another native; for the last resort of the native is to defend his personality vis-àvis his brother.
\end{abstract}

By throwing himself with all his force into the vendetta, the native tries to persuade himself that colonialism does not exist, that everything is going on as before, that history continues. Here on the level of communal organizations we clearly discern the well-known behavior patterns of avoidance. It is as if plunging into a fraternal bloodbath allowed them to ignore obstacle, and to put off till later the choice, nevertheless inevitable, which opens up the question of armed resistance to colonialism. Thus collective autodestruction in a very concrete way is one of the ways in which the native's muscular tension is set free. All these patterns of conduct are those of the death reflex when faced with danger, a suicidal behaviour which proves to the settler (whose existence and domination is by them all the more justified) that these men are not reasonable human beings. (Fanon 1967: 54)

His writing about violent phenomenon, fratricide, pent-up anger and the ritualistic dances and rites associated with it in colonial Africa are some of most vivid and imaginative passages in his writing and, for me, spoke to the dancehall culture that emanated from Jamaica and how it was in part shaped by its colonial/post-colonial social and economic context and how dance, as ritual, was a way form of exorcism of the psychological and muscular tension that results from colonial and alienating environments; how we unleash our demons through dance often as enactments of violence and symbolic killings which, in the reggae dancehall and hip hop context, often result in actual acts of fratricide:

The native's relaxation takes precisely the form of muscular orgy in which the most acute aggressivity and the most impelling violence are canalized, transformed and conjured away. The circle of the dance is a permissive circle: it protects and permits. At certain times on certain days, men and women come together at a given place, and there, under the solemn eye of the tribe, fling themselves into a seemingly unorganized pantomime, which is in reality extremely systematic in which by various means-shakes of the head, bending of the spinal column, throwing of the whole body backwards - may be deciphered as 
in an open book the huge effort of a community to exorcise itself, to liberate itself, to explain itself.... There are not limits - for in reality your purpose in coming together is to allow the accumulated libido, the hampered aggressivity, to dissolve as in a volcanic eruption. Symbolic killings, fantastic rites, imaginary mass murders - all must be brought out. The evil humors are undamned, and flow away with a din as of molten lavas. (Fanon 1967: 57)

In this sense, it helped to marry the context of the Global South with my experiences in the Global North. Later I discovered how poet Linton Kwesi Johnson (LKJ) drew on these passages in some of his early poetry as a way of discussing violent phenomena in Britain in the 1970s:

\author{
night number one was in brixton \\ soprano B sound system \\ was a beating out a rhythm with a fire \\ coming doun his reggae-reggae wire \\ it was a soun shaking doun your spinal column \\ a bad music tearing up your flesh \\ and the rebels them start fighting \\ the yout them jus turn wild \\ it's war amongst the rebels \\ madness...madness...war. (Johnson 2002: 6)
}

But as both Fanon and LKJ point out, this internalized violence often eventually becomes externalized in the form of canalized anti-colonial liberation struggles, an organized movement against colonialism and oppression. This is Fanon's dialectic, a situation in which the conditions become so unbearable that the colonized believe they have no choice but to confront those circumstances through struggle:

During the struggle for freedom, a marked alienation from these practices is observed. The native's back is to the wall, the knife is at his throat (or, more precisely, the electrode at his genitals): he will have no more call for his fancies. After centuries of unreality, after having wallowed in the most outlandish phantoms, at long last the native, gun in hand, stands face to face with the only forces which contend for his life - the forces of colonialism. (Fanon 1967: 58)

\title{
Nationalism
}

Fanon's writing on nationalism is also important. He unambiguously wrote about the betrayal of nationalist leaders, some of whom, having come to power 
Interface: a journal for and about social movements Volume 5 (1): 128 - 150 (May 2013)
Article

Austin, Choudry, D’Souza, Thobani, Reflections on Fanon

by riding the wave of popular nationalist sentiment and struggle, eventually betray the interests of their followers.

The people who at the beginning of the struggle had adopted the primitive Manicheism of the settler - Blacks and Whites, Arabs and Christians - realize as they go along that it sometimes happens that you get Blacks who are whiter than the Whites...the fact of having a national flag and the hope of an independent nation does not always tempt certain strata of the population to give up their interests or privileges. The people come to understand that natives like themselves do not lose sight of the main chance, but quite on the contrary seem to make use of the war in order to strengthen their material situation and their growing power. Certain natives continue to profiteer and exploit the war, making their gains at the expense of the people, who as usual are prepared to sacrifice everything, and water their native soil with their blood. This discovery is unpleasant, bitter, sickening: and yet everything seemed to be so simple before: the bad people were on one side, and the good on the other. The clear, unreal, idyllic light of the beginning is followed by a semi-darkness that bewilders the senses. (Fanon 1967: 144-5)

But betray is perhaps not the best word as it implies that their interests were always in sync with the majority of the population. In actual fact, it is often the case that, despite the consensus that the colonial power had to go, these leaders quietly harboured aspirations of leadership that would simply mean the replacing the colonial power while maintaining the much of the colonial economic and political structure. In essence, their interests were very much in sync with the former colonial power. This, I would later discover, also applied to community leaders who often represented themselves and their interests at the expense of members of their communities, and often in the service of what Richard Iton refers to as the "prophylactic state." Conjoined with what Iton refers to as the "duppy" or shadowy states in the Global South (2008: 135, 202), we are left via Fanon with a portrait of the interconnectedness of the south to the north that illustrates certain characteristics of colonialism and domination.

\section{Fanon and modernity}

One of the merits and challenges in reading Fanon is that he is a modernist. There is a dialectic that threads through his work, the notion that as bad as circumstances can be - or as a result of dire circumstances and when the situation appears to be at its worse - change is possible. Change comes as a result of contradiction out of which a new stage in society or the new society itself comes into being. For Fanon, this means moving beyond the phantoms, rites, rituals, and customs of "pre-modern" society. To me, this is one of weaknesses in Fanon's writing insofar as he privileges a form of progress or development that overshadows or even dismisses the more communal ways of people, the place of the spirit world, and the complexity of African societies: 
And the youth of a colonized country, growing up in an atmosphere of shot and fire, may well make a mock of, and does not hesitate to pour scorn upon the zombies of his ancestors, the horses with two heads, the dead who rise again, and the djins who rush into your body while you yawn. The native discovers reality and transforms it into the pattern of this customs, into the practice of violence and into his plan for freedom.

Here, in contrasting "reality" with the spirit world, Fanon betrays certain biases which, despite some of the parallels between them, distinguishes Amilcar Cabral from Fanon. Cabral, for example, discussed how horizontal or less hierarchal and more communal societies were more resistant to colonization than those societies that were more vertically structured and therefore assumed to be more complex. In other words, the stratified, vertical societies were more inclined to collaborate with the colonial regime. This is an important consideration that perhaps only a keen observer of African history and culture - as opposed to solely politics - could see.

\section{Teaching Fanon and his legacy}

This said, teaching Fanon is always a pleasure as his ideas speak to particular experiences which can ultimately be universalized to a range of experiences. His analysis of violence speaks to any context where oppression, poverty and misery exist, whether it is in Glasgow or Johannesburg. When he writes about nationalist leaders, he is speaking about class aspirations and leaders across the globe in ways that both speak to race and look beyond it. His psycho-social analysis of ritual and dance speak to dancehall and rave subculture and our need for cathartic release, all of which is to be found wherever we find humans. Fanon attempts to speak to the best of our humanity and the challenges of creating the future in the present and envisioning a new society in which to be human is a work in progress, an unfinished movement:

Come, then, comrades; it would be as well to decide at once to change our ways. We must shake off the heavy darkness in which we were plunged, and leave it behind. The new day which is already at hand must find us firm, prudent, and resolute.

We must leave our dreams and abandon our old beliefs and friendships from the time it all began. Let us waste no time in sterile litanies and nauseating mimicry. Leave this to Europe where they are never done talking of Man, yet murder men everywhere they find them, at the corner of every one of their streets, in all corners of the globe. For centuries they have stifled almost the whole humanity in the name of a so-called spiritual experience. Look at them today swaying between atomic and spiritual degradation. (Fanon 1967: 311)

Come, then comrades, the European game has finally ended; we must find something different. We today can do everything, so long as we do not imitate 
Interface: a journal for and about social movements Volume 5 (1): 128 - 15 O (May 2013)
Article

Austin, Choudry, D’Souza, Thobani, Reflections on Fanon

Europe, so long as we are not obsessed by the desire to catch up with Europe. (Fanon 1967: 312)

For Europe, for ourselves, and for humanity, comrades, we must turn over a new leaf, we must work out new concepts, and try to set afoot a new man. (Fanon 1967: 316)

\section{About the author}

David Austin is the author of Fear of a Black Nation: Race, Sex, and Security and Sixties Montreal (Toronto: Between the Lines, 2013) and the forthcoming The Unfinished Revolution: Linton Kwesi Johnson, Poetry, and the New Society (Jefferson, NC: McFarland, 2014). He is also the editor of You Don't Play with Revolution: The Montreal Lectures of C.L.R. James (Oakland: AK Press, 2009). In 2007 he produced Frantz Fanon: The Wretched of the Earth for CBC. He currently teaches in the Humanities, Philosophy, and Religion Department at John Abbott College in Montreal.

\section{Aziz Choudry}

\section{When did you first encounter Fanon, in what context, and how did it impact you?}

I first read The Wretched of the Earth, (along with Aimé Césaire's Discourse on Colonialism) when I was 17 or 18 . I came across it by following some reference to it somewhere, in a public library in South London. Back then, I was struggling for a vocabulary, a language to understand and deal with the racism and racist violence of the early 1980s. From the far-right fascism of the National Front and British Movement, to the endemic police brutalization and harassment of Black and Asian communities, things felt brutal, oppressive and sometimes explosive. It was Thatcher's Britain, and around the time that 'Free Nelson Mandela' and 'Racist Friend' by The Specials were in the charts. The British Army occupation of the North of Ireland, the Cold War, the threat of nuclear annihilation, and the apartheid regime in South Africa ground on. Fanon's trenchant critique of the dehumanization and alienation wrought by racism and colonialism and assertion that "the colonial world is a world cut in two", divided by barracks and police stations seemed as eerily and equally relevant in Brixton, Belfast and Derry, as it later did in explaining divisions within the environment and peace movement in Aotearoa/New Zealand between those - predominantly Pakeha/white activists - unable or unwilling to see the violence inherent in colonization and those -especially Indigenous Peoples and Pacific Island people-who opposed militarization and nuclearization of the Pacific through an understanding of colonialism. My first 
Interface: a journal for and about social movements Volume 5 (1): 128 - 150 (May 2013)
Article

Austin, Choudry, D’Souza, Thobani, Reflections on Fanon

reading of Fanon was a pretty personal, private encounter - in hindsight, a study circle or having at least someone to talk about the ideas would have been great. While I have come across much of his other work translated into English since then, it's still The Wretched of the Earth that draws me back again and again.

What I remember most was the impact of the passion, poetry, drama and clarity of thought. While I've certainly never seen Wretched as some sort of a manifesto, it is difficult not to use the words 'prescient' and 'prophetic' about Fanon. Perhaps it is a false exercise to accurately assess the extent to which Fanon's ideas shaped my analysis first as an organizer, as an activist, and later in life as someone who currently works in the university as a professor in a faculty of education. Yet Fanon has always been there in some form, and in terms of impact, for me, ranks as possibly the most influential thinker. I was not really around academia much until recent years, so my introduction to him was more in the context of my own growing anti-colonial activism and analysis and was not particularly linked to formal education.

\section{Universal and particular}

I re-encountered Fanon in the course of activism in Aotearoa/New Zealand, after ending up there in the mid-1980s, and was struck by how his work and ideas had been discussed, debated, and taken up in different contexts. Apart from a year in a university undergraduate program, before 'dropping out', mine were, for the most part, not 'academic' engagements with Fanon. In the context of Indigenous struggles for self-determination in the Pacific, in settler colonial states like Aotearoa/New Zealand and Australia, and perhaps most obviously in regard to France's remaining Pacific colonies - Kanaky (New Caledonia) and "French" Polynesia, Fanon's ideas were present in many conversations around struggles for decolonization and self-determination. In particular I recall conversations in the early 1990 s with Kanak independence activist Susanna Ounei, (from French-occupied Kanaky/New Caledonia), about the lessons from Fanon in the context of the Kanak independence struggle and, more broadly, in the Nuclear Free and Independent Pacific movement/network of struggles. Just as the Caribbean and the Pacific islands share some commonalities in their histories of colonialism, there are obvious parallels between French nuclear testing, brutal colonial/military occupation and war in Algeria and French colonialism in the Pacific. I've often thought of how France was conducting its nuclear tests in Algeria at the start of the 1960s, in the last two years of Fanon's life, and the way that testing moved to Mururoa in 1962 (with tests again in the mid-90s). Then there was the Ouvéa massacre of 19 Kanak activists by French security forces in 1988, alongside ongoing militarized occupation of the territory. In the South Pacific, it did not seem to me that one had to look too far or too hard to appreciate Fanon's notion that colonialism is 'violence in its natural state'. 
And in so many contexts, it seems that the questions which he highlighted about the perils of bourgeois nationalist leadership replicating colonial rule after the colonizers had allegedly 'left', (and of the potential of 'post-independence' nationalism turning to xenophobia), were in the minds and conversations about leaders and elites who emerged from liberation movements. These were the very same tensions, possibilities, caveats and warnings that Fanon shared on 'the pitfalls of national consciousness.' He offered warnings/analysis that instead of true decolonization, elites involved in national liberation struggles can end up becoming collaborators in replicating the structures of the colonizer, and actors of neocolonialism at a time of formal freedom, betraying any transformative potential of the liberation struggle. The changing of the flag but simply replacing it with neocolonial elites. Unfortunately we have seen that in too many contexts.

Conversations with Maori friends about the decolonization of the mind and relating this to the meaning of decolonization in other context of struggles for self-determination in the Pacific referenced Fanon. His work certainly had an influence on a number of important Indigenous mental health, community and social work initiatives, grappling with the psychological effects of colonization.

Long before the word 'globalization' became so ubiquitous, and before the technology of the Internet, Fanon's ideas had travelled widely in liberation movements --especially those for whom the concept of self-determination had not been jettisoned or supplanted by some other concept like "sustainable development," as Radha has discussed elsewhere. For I think it's sometimes easy to overlook the ways in which, through diasporas and international links between movements and struggles, those ideas and debates of which Fanon was such a major part travelled far and wide. I thought and still think that Fanon spoke to people's lives and struggles not as some abstracted disembodied, objectifying, academic voice, decontextualized from the conditions in which he lived, struggled and wrote.

That was also the context in which I first met Radha and Sunera - through struggles in the 1990s against the free market reforms in Aotearoa/New Zealand and their relations with historical and contemporary forms of colonialism and capitalist globalization, free trade and investment agreements like GATT/WTO (General Agreement on Tariffs and Trade/World Trade Organization, forums like APEC (Asia Pacific Economic Cooperation), etc. For me, the anti-colonial, anti-racist politics came first. My 'anti-globalization', or 'global justice' organizing was informed by, and framed within that. In turn, alongside questions about whether the "anti-globalization" movement was inherently anticapitalist, a few of us pointed out that it was not inherently anti colonial.

On that note, writing while ill - and ultimately dying from myeloid leukemia in 1960-1961 - Fanon's visionary analysis of imperialism in post-independence Third World nations predicts a scenario where nominally decolonized societies contend with attendant capital flight, and direct colonial rule is replaced by the intensification of foreign investment imperialism which locks newly independent peoples into new forms of exploitation, facilitated by nationalist 
elites. I was re-reading the chapter "The pitfalls of national consciousness" (from Wretched of the Earth) the other day and thinking about how well it spoke to the last three decades or more of structural adjustment policies, trade and investment liberalization, examples of post-independence leadership which collaborates with former colonial powers, capital and which uses military repression against the masses and thinking, "yes, he got that right!"

Years later, I remember a conversation David and I had on the street outside of Concordia University in Montreal, when we talked about how Fanon had been taken up at the same time in black struggle in Canada, North America, the Caribbean, by Red Power (Indigenous activists) and sections of the white Québecois(e) nationalist left. Talking again recently about his new book, Fear of a Black Nation, David made an interesting point about the politics and history of language/translation, about how and when exactly Fanon and Césaire were being seriously taken up in Québecois(e) communities in the original French - before English translations of his work started circulating in oppositional movements, and what that meant in terms of the influence of his thought on respective movements. Alongside that, I think that Sunera's work, more than most in Canada, has consistently invoked and built upon the insights that Fanon has made which connect colonization, racialization and violence in both domestic and global contexts.

\section{Teaching Fanon}

A key aspect of Fanon's contribution is his recognition of the intellectual work, the dialectic of learning, in the struggle - with all of its tensions and contradictions. He is clear not to set up some kind of dualistic notion about 'the brain' and 'the brawn' of movements, viewing that both reason and force have great importance in popular mobilization, and are dialectically related. In the context of struggles for liberation, Fanon noted how ordinary people have the potential to take control over their lives, that their consciousness emerges through struggle. Staughton Lynd reminds us that "without exception the most significant contributions to Marxist thought have come from men and women who were not academics, who passed through the university but did not remain there" (2010: 144). In my view, Fanon has to be included in that list.

With a few exceptions, I was surprised and sometimes dismayed at some of the ways that Fanon's work is read in academe. Randall Williams has written perceptively about the "selectivity and wariness with which the revolutionary theorists of decolonization - Césaire, Fanon, Cabral, Rodney, etc. - are received or ignored today" (2010: 105). I have had some pretty surreal conversations with some academics about Fanon in which they seem to have rendered invisible the person, his struggles, his politics and the context in which he wrote. On the one hand, these responses sometimes remind me of a crude, and I think, rather anti-intellectual claim that he somehow glorified or fetishized violence. This is redolent of one time when I had the misfortune to be watching some US TV crime drama where police raid some "homegrown terrorist"s house and the 
camera zooms in on the suspect's bookcase with the Wretched of the Earth prominently displayed. On the other, there are some very strange abstractions of Fanon's work that seem so far removed as to be unrecognizable.

In teaching Fanon, I use Cheikh Djemai's film "Frantz Fanon: une vie, un combat, une oeuvre". In teaching Fanon's writings, life, struggle, and work, what's encouraging is the interest among some students - many, but not exclusively, racialized students-in looking at Fanon's ideas to think through contemporary/recent issues, struggles and dilemmas. Perhaps it's interesting to think about why it is, and with whom one can say, that Fanon's work does and doesn't resonate. I tend to use "Concerning Violence" from Wretched regularly in courses on international 'development' and education. It remains hard to move past a reading of the chapter which does not fixate on, and decontextualize, his discussion of violence. A student in one of my classes recently said "he's too black and white". But I've always read it as a powerful critique of the inherent violence in colonialism. On the other hand I recently did a reading course on anti-colonial literature with one of my graduate students, which traversed Césaire, Fanon, Amilcar Cabral, Walter Rodney and Steve Biko among others. Reading them together was a fabulous way for both of us to think through their contributions for today.

\section{Fanon's legacy}

Lately I've been in many conversations, inside and outside of the university context, about how we - as educators, organizers, activists--can learn from conceptual resources from earlier struggles, rather than reinventing the wheel. There is much to be said for reading Fanon against the contemporary times that we live in. The materiality and intensity of Fanon's writing still leaps off every page. Of course, we cannot and should not overlook the geohistorical aspects of the moment(s) in which he wrote, the time and place, the political and social contexts, how these were shaped by his experiences in Martinique, France, Algeria, Tunisia, and informed by his political commitments and engagements. But obviously his legacy is terribly important-- as evidenced by the fact that there were so many commemorations of his life, work and struggles in so many places in late 2011/early 2012, marking 50 years after his death in December 1961. Sitting with friends and comrades recently in South Africa, affirmed to me how his ideas are clearly relevant for many of those who struggled against apartheid only to find the old regime replaced by governments which, in the name of liberation, seem to have prioritized the interests of capital over the masses. What's exciting is to see a new generation of organizers, and students encountering, rediscovering, or in a sense unearthing, Fanon. Some Fanon reading/study circles wouldn't be a bad thing in both movement and more academic contexts, indeed perhaps encompassing both.

In my mind, I've long bracketed Fanon's The Wretched of the Earth with that powerful poem by Pakistani revolutionary poet Faiz Ahmad Faiz, "Subh-eAzadi", The Dawn of Freedom. It's not just that they both warn of betrayal by 
nationalist elites at the moment of supposed liberation or independence. It's also their profound sense of, and faith in, humanity, alongside their condemnation of the dehumanizing effects of imperialism and colonialism. While perhaps it might be easy to be cynical and dismissive of popular struggles for change, and people's efforts to emancipate themselves from oppression, Fanon was deeply committed to thinking through the difficulties and complexities of the process of decolonization in a way which offered hope. As his former colleague and biographer, Alice Cherki suggests, The Wretched of the Earth cannot be dismissed as an outmoded text "if we choose to read [it] as an appeal to the future and what it can hold" (2000: 221).

\section{About the author}

Aziz Choudry is a longtime activist who is currently Assistant Professor in the Department of Integrated Studies in Education at McGill University, Canada. He is co-author of Fight Back: Workplace Justice for Immigrants (Fernwood, 2009), and co-editor of Learning from the Ground Up: Global Perspectives on Social Movements and Knowledge Production (Palgrave Macmillan, 2010), Organize! Building from the Local for Global Justice, (PM Press/Between the Lines, 2012), and NGOization: Complicity, Contradictions and Prospects (Zed Books, 2013). He is on the global spokescouncil, and a regional editor, for Interface.

\section{Radha D'Souza}

\section{When did you first encounter Fanon, in what context, and how did it impact you?}

I first heard about Frantz Fanon as an undergraduate student studying in the University of Bombay. The post-Independence euphoria had ebbed away in India by then. India, one of the first colonies to become independent, the home to Gandhi, was also the first to be disillusioned by it on a national scale. By the mid-sixties the economy had all the trappings of a dependent colony. Poverty and famines were everywhere, the World Bank for all practical purposes wrote the nation's five year plans, and the IMF forced devaluation of the rupee. The Naxalbari uprising, a small peasant revolt in the remote Terai regions on the foothills of the Himalayas, was a spark that fell on the tinderbox of a disillusioned nation. Naxalbari led to widespread state repression. Thousands of young people were 'disappeared' by the state or killed in 'encounters'(extrajudicial killings). Naxalbari added to Indian-English words that are part of the vernacular vocabulary of state violence to this day. Naxalbari was followed by the national railway strike and the national Emergency when the Bill of Rights provisions in the constitution were suspended and the pretence of democracy 
ended. To be young was a big security risk, and to be a young man with an attitude an enhanced security risk.

During the Emergency many of us suddenly found ourselves with more time on hand. Without strikes, protests, and demonstrations to organise, a time when even hanging out in cafes came with safety risks, we decided to use our time productively by reading. A university professor who was and still is very supportive of students suggested we read Fanon. I remember clearly our reaction on discovering Fanon for the first time. We felt vindicated, our views about the events around us were validated by someone who was not from our country or context. We were not 'mindless' or 'misguided' as the state and the media portrayed us. We were saying national independence was not supposed to become what it had. State violence was the cause of social violence.

Two and a half decades later I rediscovered Fanon in New Zealand as an academic. Ironically Bombay had been renamed Mumbai, after a campaign spearheaded by the militant Hindu organisation Shiv Sena in 1995 after the demolition of the ancient Babri Masjid mosque in 1992 in Uttar Pradesh. The events leading up to the Babri Masjid were filled with anti-Muslim hysteria and followed by widespread violence against Muslims throughout India. Ironic because the rioters and the victims were both the 'wretched of the earth', drawn from the slums and ghettoes of Bombay, a city marked by what Fanon described as the 'geography of hunger'. Ironic because way back in the sixties Fanon grasped the anatomy of aggression by the oppressed. The colonised man dreams of physical prowess because aggression is 'deposited in his bones'. 'Niggers', Fanon wrote, beat each other up, and there is collective 'auto-destruction'. Poverty and police powers, the two faces of oppression, dehumanises.

The Fanon I rediscovered in New Zealand academia, in Spanish and postcolonial studies, had gone from being a serious champion of the Third World oppressed to becoming a kind of 'cool guy', laundered and pressed by the socalled 'cultural turn' in social theory. Critical theory had transformed Fanon almost beyond recognition. A black man's desire to wear a white mask was no longer about colonisation, oppression and state violence. It became a matter of black "identity", a particular way of engaging racial discrimination that reduced colonialism to a racial question and lead the way smoothly to the politics of multiculturalism. State violence, economic violence, cultural violence, and violence of history, at the forefront of Fanon's critique of colonisation became quiet and invisible, and if mentioned at all, it was only through the lens of identity, as sources for identity formation. Identity was a consequence of violence not the thing itself.

I was astonished to read that Fanon was seen as the 'prophet of violence' by many academics. Surrounded by daily state violence it had never crossed our minds that Fanon could be read in that way. I had learnt that Machiavelli and Hobbes were the prophets of violence. Machiavelli advised the wise prince to use violence judiciously as a technique of statecraft and Hobbes said the power of the body politic rested on the sword. In academia, people around me cited both scholars of Western Enlightenment but rarely if ever associated their thesis 
Interface: a journal for and about social movements Volume 5 (1): 128 - 150 (May 2013)
Article

Austin, Choudry, D’Souza, Thobani, Reflections on Fanon

on violence with the modern state which institutionalises and monopolises violence.

In 2011, in the UK by then, I searched to see if there were people who might want to celebrate the life of Fanon in the year of his fiftieth death anniversary. By then, even the cultural and postcolonial theorists had nearly forgotten Fanon in British universities. Neoliberal reform of universities, the successive decimation of trade unions and austerity measures had switched intellectual ethos in academia to TINA mode - there is no alternative but to succumb to restructuring and reforms and put one's head down to survive. These are tough times. Fanon was no longer the 'cool guy' of the eighties and nineties. Fanon was remembered instead in the Afro-Caribbean communities in London, many of whom were still reeling in the aftermath of the Tottenham riots in August 2011 when young black men and women once again demonstrated, very tragically, Fanon's understanding of the anatomy of state violence on the 'wretched of the earth' in the heartland of global finance capital. The British Afro-Caribbean community organised a public event to celebrate Fanon's life. One speaker, a Ghanaian recalled how as a young man and early career journalist he had interviewed Fanon, and reported on his tour of Africa, his visit to Ghana and meetings with Nkrumah in the early days of Ghana's independence. Fanon came to life at the meeting. Women wept as they spoke of police mistreatment of their sons and grandsons. 'Our children are not bad; they are good kids', one of them said. The simplicity of her words moved the audience to tears. I remembered Fanon's quote from his teacher and black poet Césaire in The Wretched of the Earth. There is an exchange between a rebel and his mother there that echoed the words of the mother on the stage in London. Fanon belongs to the AfroCaribbean communities and I am glad he was celebrated by them. It did not matter to me anymore that the multiculturalists in the Universities had forgotten him.

\section{Violence}

Fanon was a psychiatrist, a trained medical practitioner. He was also a black man from the French colony of Martinique whose ancestors were slaves. He fought in World War 2 and experienced the most extreme form of state violence: war. Practicing as a psychiatrist in Algeria, he saw from close quarters what colonisation did to the 'human' in human beings. He became interested in the Algerian revolution because of the torture victims who came to him for treatment in the aftermath of the bloody repression of the nationalist movement in France. He moved to Algeria because he saw that as a black man, even a brilliant one, in France in the fifties his practice could not flourish. By then he had experienced French racism firsthand and written Black Skin, White Masks. Why do people endure so much suffering and pain for the sake of freedom and national independence? This question led him to interrogate colonialism and imperial domination. 
Interface: a journal for and about social movements Volume 5 (1): 128 - 150 (May 2013)
Article

Austin, Choudry, D’Souza, Thobani, Reflections on Fanon

The edifice of modern capitalism was founded on colonialism, the slave trade, the land confiscations, the appropriation of natural wealth and labour. In turn colonialism was a system organised and maintained by naked violence. The violence of colonialism was physical, social, economic, cultural and emotional. Colonial societies were founded by violence and maintained through it. What does a society founded on violence do to its members? On the one hand it could destroy their sense of self so completely that they became benumbed and dehumanised, a pathetic shadow of the human spirit. However, on the other, the human spirit being indestructible invariably found an outlet through spontaneous violence- which could be either individual violence against others equally wretched or collective violence of the poor that came out in outbursts like riots. Either way this violence was intuitive.

The violence of a freedom fighter is qualitatively different in contrast. The freedom fighter begins by saying 'I am not putting up with this 's...' anymore'. The moment s/he resists, the colonial state unleashes extraordinary violence upon him/her. The resistance fighter targets the perpetrator of violence with the hope of ending it forever. Revolutionary violence restores humanity in the abused, tortured individual. The act of resisting returns dignity and sense of self which the oppressor's violence had destroyed. When a person says 'I am not putting up with this 's...', s/he ceases to be the animal s/he has been reduced to by the coloniser. The restoration of their humanity is crucial if there is to be freedom at all. The freedom fighter is able to endure extreme trauma because $\mathrm{s} /$ he hopes by doing so s/he can keep her/his humanity which s/he has briefly tasted in the act of resistance.

I want to step back from Fanon for a moment in order to locate the wider significance of his contributions on understanding violence of the oppressed in the post World War 2 era. There are three wider points I wish to make.

First, it is important to remember that the critique of Fanon by critical theorists like Hannah Arendt turns on philosophical arguments that reflect postHolocaust angst among European intellectuals. The philosophical response to European intellectual angst provided the moral justification for seeking reparations from Germany which in turn was used to colonise Palestine and establish the newest colonial-military state of Israel. If violence begets violence which is true as a philosophical argument - who should bear the responsibility for ending the cycles of violence? The solution for European intellectuals was reparations from Germany (repentance), the use of that money to establish the state of Israel (compensation), and political solution as opposed to armed struggle for a Palestinian homeland and self-determination (non-violence). In this context it is interesting to recall another philosopher of non-violence from the East who took a completely different view on the responsibility for ending cycles of violence. The Buddha in his sermon to Pranjit and Ajatasatru in sixth century $\mathrm{BC}$ also argued that violence begets violence. But he concluded that cycles of violence must and can only be ended by the victors. In this school of thought in the European context the onus would fall on the Allies to dismantle the institutions of violence. Predictably the Allies went on to build formidable 
Interface: a journal for and about social movements Volume 5 (1): 128 - 150 (May 2013)
Article

Austin, Choudry, D’Souza, Thobani, Reflections on Fanon

military-industrial-commercial - media complexes after winning the World Wars.

Fanon's arguments in contrast were based on clinical observations and conclusions he came to from healing real people in a repressed colonised society. The starting point for him was not ethical or political philosophy but a real human being who had come to him to be healed. What should that human being do until the victors dismantle their military-industrial-media complexes? Violence is not about using particular tools - it is not about a knife, or a gun, or a machine gun, which can be picked up or dropped down depending on political 'choices'. Lenin argued that wars mobilise entire societies and that wars reorganise all of society. Before him Engels argued in Anti-Duhring that wars were not about weapons alone but the political economy of production, distribution and consumption of weapons. The military-industrial-commercialmedia complexes of the post WW2 era reorganised the societies that were victorious in the World Wars, the Allies, as gigantic warfare states by unifying institutions of state and defence establishments, monopoly corporations and institutions of commerce and civil society and institutions of knowledge. When unmanned drone missiles rain bombs on 'mistaken targets' and families of peasants and shopkeepers on the ground become 'collateral damage' what should those people do while they wait for the philosophers of non-violence to convince their warfare states to dissolve themselves?

My second point is about 'agency' and 'subjectivity'. At least since the so-called 'cultural turn' critical theory on the Left has systematically undermined structural analysis in favour of subjectivity and agency. On the Right neoliberalism has elevated individual 'choice' to new levels. Individuals, in the neoliberal conception, are motivated by self-interest and seek to maximise gains by making the right choices. Too bad if their choices are not in sync with market fluctuations. 'There is no such thing as society' as Margaret Thatcher famously said and there will be 'winners and losers'. The conceptualisations of agency in the post-World War 2 era marked by the so-called 'cultural turn' in theory, objectifies agency and transforms subjectivity into an object for philosophical contemplation. It obscures the fact that agency is an attribute of the psyche, the emotional, psychological and moral dimensions of life. Cultural theories integrate the emotional, psychological and moral aspects of life into structures of state and oppression. Foucauldian 'disciplinary power', and the Gramscian 'hegemony' includes agency in the structures of governance and thereby subsume the autonomy of agency in the real life of real people. It forecloses possibilities of transformative structural change. This is the paradox of 'agency' and 'subjectivity' in critical theory. Fanon's question never presented itself to the critical theorists: what should the torture victim mauled by French intelligence service officers, or the peasants systematically dehumanised by the colonial state do? What of their 'agency'?

Fanon's position as a psychiatrist put the question squarely before him, and his practice in Algeria during the revolution and its repression meant the question could not be answered without considering colonialism. The option of 
Interface: a journal for and about social movements Volume 5 (1): 128 - 150 (May 2013)
Article

Austin, Choudry, D’Souza, Thobani, Reflections on Fanon

developing a more sophisticated panopticon was not available to him. What makes Fanon a revolutionary thinker is that he did not shy away from answering the question that the context presented him with. Colonisation and state violence dehumanises people. Period. Resistance restores the psychological, emotional and moral dimensions of a dehumanised person by restoring 'agency' to him/her in real life. He was always clear that violence must end but equally clear that it could end only when the architecture for violence was dismantled - colonial appropriation and expropriation must end for state violence to end, and when institutional violence ended, individual violence will become a minor, local and community based problem, as opposed to being a systemic foundation of society as it is at present.

That brings me to the third point about violence which is a far more insidious development since Fanon's times. There are two strands of early Enlightenment and modernisation and their coming together in the post-World War era that is significant. First, the Age of Enlightenment introduced a rupture between the material world and the mental world. This rupture created the body-mind or mind-matter dichotomy that is the hallmark of nearly all schools of Enlightenment thought. However, with the rise of monopoly finance capitalism in the early twentieth century, we find the emergence of psychology as a distinct "science" subject to "scientific methods" of empirical verification and experimentation that could be treated by combinations of medical and social sciences. Psychology is a quintessentially American-led "science" of the twentieth century. Its expansion into "social psychology" and "behavioural" psychology expanded methods of this science of psychology to collective "minds" as opposed to individual responses to situations. Psychology transformed the old 'body-mind' problem in qualitative ways by taking it beyond the realm of ethical philosophy to interventions through clinical and social "treatments".

The engines driving the expansion of the scope and character of psychology were twofold. The Age of Enlightenment produced an extraordinary innovation - the corporation. Conceived initially by merchants as a risk management strategy the corporation was endowed with 'juristic personality' - i.e. it was a 'person' analogous to the natural person. The transformation of corporations from being small risk management societies to monopolies in the early twentieth century created the need for command-communication-control systems within organisations. If monopolies were to be counted as a single a juristic 'person', then they needed to operate with a single 'mind'. Behavioural psychology and social psychology provided the knowledge base for large organisations to functions with a single 'mind'. Fields like 'social psychology', organisational 'behaviour', organisational 'psychology', corporate social 'responsibility' held out the possibility that the juristic person could have a 'mind' similar to the natural person. Behavioural psychology endowed 'juristic persons' with a 'mind'.

Secondly, the rise of new forms of militarism in the early twentieth century, in particular, the invention of airplanes and the emergence of aerial warfare 
Interface: a journal for and about social movements Volume 5 (1): 128 - 150 (May 2013)
Article

Austin, Choudry, D’Souza, Thobani, Reflections on Fanon

created the demand for what is called $3 \mathrm{C}$ technologies - CommandCommunication-Control technologies. $3 \mathrm{C}$ technologies in turn involved communication between machines and humans and machines and broke down the most important barrier between men and machines: the psyche. Cybernetics was born during that period, and developments in artificial intelligence, robotics and such brought together a number of social and natural sciences including linguistics, sociology, anthropology and psychology besides biology, chemistry and physics. $3 \mathrm{C}$ technologies provided the technological underpinnings for corporate communications and corporations provided the manufacturing facilities for $3 \mathrm{C}$ technologies. The juristic person became endowed with a 'psyche'. The natural person became a pale, emaciated and powerless shadow in competition with the juristic person. Postmodernism, cultural and critical theories, as Zygmunt Bauman argues in his book Legislators and Interpreters succumbed to the emaciation of the individual. They succumbed to it however by accepting the juristic person as a 'psyche-bearing' person. Fanon never succumbed to this possibility. The juristic person with a psyche was an embodiment of violence, it was colonialism itself, it was the integration of economy, state and civil society in the architecture of societies founded on violence. The psyche was for Fanon an attribute of being human and human beings alone were capable of transformative social action. Healing the social and individual psyche destroyed by the monstrosities of military-industrialcommercial-media complexes was possible not by theorising about subjectivity but by transformative social action. Resistance was therapy and resistance brought social change. This revolutionary insight calls for restoring the unity of the body, the mind and the body politic through transformative action. Fanon was a revolutionary far ahead of his times.

\section{Nationalism}

Fanon never saw formal national independence as an end in itself. Equally he saw the Third World elite clearly for who they were and what their success entailed for the 'wretched of the earth'. Fanon never fell into the capitalismsocialism dichotomy of the Cold War. Socialism unleashed the enthusiasm of people whereby they subjected themselves voluntarily to forced labour. Independence forced Third World societies to the same forms of production as under colonialism. Yet socialism and nationalism opened the way for new and creative social reconstruction. The new society he argued cannot emulate the old, or be founded on the value systems of the old society. And, we cannot afford to forget that the grandeur of Europe rests on the wealth appropriated from the rest of the world - Europe was a creation of the Third World, he argued. The Third World cannot reclaim itself by emulating Europe. They must find their own values and methods particular to them, and when doing so, they cannot afford to forget the extraordinary violence that will inevitably befall them. The Third World must choose its own path. Fanon leaves the National Liberation project wide open even after formal independence. In this, Fanon was clearly far 
ahead of his times and foresaw the trajectory and limitations of national liberation struggles even when supporting them.

\section{Teaching Fanon}

Fanon is outside the bounds of legal education. The day Law Schools include Fanon in their curriculum will signal the beginnings of a world that takes a violence-free world seriously.

\section{About the author}

Radha D'Souza teaches law in the University of Westminster, London. Her research interests include global and social justice, social movements, Law and Development, colonialism and imperialism, socio-legal studies, law and technology, and resource conflicts in the Third World, in particular, water conflicts. Radha loves literature and people.

\section{Sunera Thobani}

\section{When did you first encounter Fanon, in what context, and how did it impact you?}

I first read Fanon when I went to college as a mature student in the UK to study for an undergraduate degree in the Social Sciences. My family had migrated from Tanzania to England as part of the early 1970s wave of Asian migration in response to the Africanization policies that followed independence from British rule. I grew up in the highly charged racial politics of Tanzania, where Asians had been brought in from India during the late $19^{\text {th }}$ and early $20^{\text {th }}$ century under colonial (German and British) rule to serve as the buffer between the European settlers/colonial administrators and the larger African population. I was thus acutely aware of the violence underpinning this society on an experiential level, but little in my schooling or community life actually acknowledged this reality. My family was working class, but part of a conservative Asian community that had played a key role in furthering the socio-economic policies of the colonial state. And although my family would have had little to lose from the nationalization of property initiated by the postcolonial state after the Arusha Declaration, they decided to migrate to the UK as our community began to leave and rumours abounded about young Asian women and girls being forced into marriage with older African men.

The racism of the 1970s UK - especially in the streets against working class Asian families - was intense, yet we had no language, no tools in my family to even name this, let alone try and confront it in any fashion. There were no community organizations that provided any support, and religious institutions 
in the community tended to be very conservative. The grind of daily survival wore my family down, the trauma of migration remained fresh year after year, and the alienation we felt from the larger society left deep scars in all our lives.

After spending some years working, I decided to go to college. This possibility had never been on the horizon for any of the women in my family. When my sister and I went to college, we were breaking new ground. It was there that I read Fanon's Black Skin, White Masks, and the book utterly transformed my life. The power of each sentence in the book, the clarity of thought and the controlled fury of Fanon's politics were deeply liberating to read. Suddenly I had a language and a framework in which to understand my own experiences as well as those of my family. The sophistication of Black Skin, White Masks' analysis of intra- as well as inter- group racial violence also gave me a way to make sense of the racism of Asians against Africans in the context of the global hierarchy of races instituted by white supremacy. Fanon's explication on the role of violence in the daily reproduction of the racial/colonial order was certainly profoundly unsettling, as was his description of the psychic and spatial ordering of such violence. Yet at the same time, his analysis was deeply reassuring; I had seen and experienced the anger he described erupting in the world around me, anger that until then had seemed inexplicable. Reading Fanon helped me acquire a historical understanding of the colonial order with its global system of racial hierarchy, and of the psychic as well as the material effects of racism and white supremacy.

It is difficult even now to put into words the powerful impact Fanon's ideas had on my thinking. I joined anti-racist organizations while in college, started going on protest marches, and began to understand more fully the meaning of the Brixton and Southall riots as they had erupted in the streets of London. My politicization had begun and there was no turning back after reading Fanon. In many ways, reading Fanon at that point in my life saved me.

\section{Violence}

Fanon's famous contention that it is primarily violence that sustains the racial and colonial order highlighted the inextricability of physical conquest and material deprivation from the psycho-sexual aggression that sought to destroy the natives' languages, customs, sexual and gender norms, as well as their historical consciousness, and indeed, their very status as human. The resulting forms of alienation transformed the colonized 'wo/man' into a 'thing' existing in an intense state of politico-cultural and psycho-sexual depersonalization. Only a radical decolonization that replaced a particular 'species' of wo/man with another could enable colonized peoples to reclaim their stolen humanity, argued Fanon in his defence of the Algerian revolution against French occupation. The depth of Fanon's analysis of the forms violence assumes in the organization of the global order remains unparalleled even now.

I was very interested in these ideas on violence when I first read Fanon, and find them even more relevant now in the era of the global War on Terror. Soon after 
Interface: a journal for and about social movements Volume 5 (1): 128 - 150 (May 2013)
Article

Austin, Choudry, D’Souza, Thobani, Reflections on Fanon

reading Wretched of the Earth, I went to Palestine to work as a volunteer with the Palestinian Women's Union in Gaza. Although this was before the first Intifada, I came to recognize the inevitability of revolutionary violence in the context of the colonial occupation of Palestine by the Zionist state. Israeli troops were to be found on every street corner, checkpoints shaped the experience of everyday life, controlling the mobility of Palestinian friends at every turn. As terrible as the living conditions were in Gaza at that time, the situation is now, of course, much, much worse.

In Palestine, I also came to understand, for the first time in my life, what it meant emotionally and psychically to be connected to a particular land; I also began to understand the lasting impact - through generations - of the violence of dispossession from the land. Coming from a migrant community, I had never really had any experience of this psycho-political phenomenon. But in the time I spent with Palestinian activists, I came to see the deep meaning this relationship to land had in their political vision and in the cultural expressions of their resistance to the violence of the Israeli state. After I migrated to Canada, I saw the same deep rootedness of Indigenous peoples in their relationship to the land, and came to understand that as a member of an immigrant community, my relationship to Canada is of a very different nature. Fanon's ideas thus indelibly shaped my understanding of settler colonialism, and of the urgent necessity for immigrant communities in Canada to build solidarity with Indigenous peoples' struggles for sovereignty. Citizenship has been the mechanism through which immigrant communities have become complicit in the ongoing colonization of First Nations, and any social justice movement that elides the necessity for a fundamental transformation of this institution cannot possibly bring about any meaningful social change.

After the attacks of 9/11, Fanon's analysis of the role of violence in geopolitics and his understanding of the role of revolutionary violence in the anti-colonial politics of the Algerian revolution became relevant once again in my own analysis of the War on Terror. Fanon's ideas had been central to the politics of resistance of third world revolutionary movements, and the relevance of his analysis to the violence instantiated in the 'new' invasions and occupations of Afghanistan and Iraq in the early $21^{\text {st }}$ century was undeniable.

But as Islamophobia moved to the centre of geopolitics with the invasion of Afghanistan, I was surprised at how quickly left, feminist and anti-war movements capitulated to the demonization of Muslims and Islam that was to become the ideological pillar of this new imperialism. Although many of these activists voiced their opposition to the imperialist policies of the US Administration, they were unable to see past the Western fear-mongering about the dangers of Islam, accepting the US invasion of Afghanistan as the 'lesser' danger. And this included activists who had read and understood Fanon. The 'man' living under occupation is no such entity, Fanon had claimed in his studies of the $19^{\text {th }}$ and $20^{\text {th }}$ century colonial order, finding instead in his psychiatric practice, political activism and personal experience that this order was reliant upon the transformation of the soul of the Black 'man' into the 
'artefact' of the white man. The torture and waging of state terror against Muslim populations around the world in the US-led global war was accomplishing the same 'thingification' as the Muslim wo/man was being yet again stripped of their status as 'human', namely, the rights-bearing citizensubject of modernity. The gains of previously colonized Muslim populations in the postcolonial era, including their access to citizenship rights, were being destroyed in the racial profiling, rendition, targeted assassination and collective punishment being meted out by the nation-state system, yet Islamophobia quickly became as widespread in social justice movements as it was in mainstream society. The Muslim men hunted, tortured and murdered by US forces and their allies were being defined in social justice movements as hypermisogynist woman-haters, and the Muslim women being killed by US bombs were being defined as in need only of unveiling. Race and religious identity merged in the construction of the believing Muslim as the most potent threat to global security, and Fanon's insightful analysis of the veil in the Algerian women's lives he had studied fell by the wayside. The Islamophobia rife in social justice movements today has been a profoundly disturbing lesson about the state of the politics of resistance in these movements, and convinces me of the importance of engaging with Fanon's ideas on anti-colonial politics once again if we are to understand the ongoing coloniality and raciality that is remaking the contemporary political order.

\section{Teaching Fanon}

Fanon has never been included in the required curriculum in any of the Degree programs I have taken, which have been in the UK, US and Canada. I read Fanon outside class on the recommendation of what are today called Sessional Instructors in the neo-liberal corporatized academy, i.e., part time temporary Instructors.

In a recent article for $\mathrm{Al}$ Jazeera, Hamid Dabashi has taken on this ongoing marginalization of the work of third world scholars and the privileging of white intellectuals as philosophers and theorists by asking the question 'Can nonEuropeans think?' Walter Mignolo (2013) has made an important contribution to this discussion by clarifying that his "...readings of continental philosophy are not in search of guiding lights to deal with issues of non-European histories, but an interest in what are 'they' thinking, what are 'their' concerns and what are 'they' up to." Mignolo then recommends turning to Fanon for those who are interested in understanding Eurocentrism. I am in complete agreement with this recommendation, for Fanon is as indispensable to understanding racial violence, white supremacy, colonialism and imperialism and their material, emotional and psychic effects as he is to understanding the politics of gender and sexuality. Indeed, without the exploration of the role of racial and colonial desire in shaping sexuality, any theorizing of gender relations remains suspect. Given the transformations that have taken place in articulations of the racial, sexual and gender politics of white supremacy in the War on Terror, I see teaching Fanon as absolutely key to the critical race and feminist theory 
curriculum. Although some of his writing on these issues is clearly dated, I still consider it impossible to fully grasp the impact of coloniality on questions of sexuality without studying Fanon.

But teaching Fanon is incredibly frustrating, in my experience. I teach in the field of Women's and Gender Studies and have found a deep hostility in this area of scholarship to critical race and anti-colonial studies - indeed to any body of scholarship that questions Eurocentrism. This hostility has increased steadily over the last fifteen years with the rise of poststructural and postmodern feminisms. Every time I have tried to teach Fanon, students who define themselves as feminists will inevitably dismiss him with the simplistic contention that 'he is sexist'. This is the only defence these students have to explain their refusal to engage with critical race theory and anti-colonial politics. And they cling to this defence with all their psychic might, actively contributing to the reproduction of the myth of the hyper-macho Black male.

Similarly, critical race theory, a field where one might expect Fanon's ideas to flourish, remains oblivious - with few exceptions - to the import of his insights. In this field of scholarship too, one finds much antagonism towards Fanon; his work gets dismissed as quaint but belonging to a time long past. By rendering irrelevant Fanon's ideas and thus neutralizing his critique of the violence of raciality, such dismissals further liberalist analyses of race at the cost of radical and transformative perspectives.

\section{Remembering Fanon}

Fifty years after his death, Fanon remains much maligned and misinterpreted. The wilful reluctance to engage with his work is evidence of the strength of the established order to quell dissent, an order against which Fanon positioned himself so forcefully. His work continues to provide us with the critical tools to analyze, understand and unmake the contemporary forms of power assumed by this establishment. In Fanon's call for change, we find a deep-seated anger at the dehumanization that is embedded within the global order. We also find the resources for (re)building anti-colonial and anti-racist movements. His optimism for the possibility of radical change is inspiring and life-affirming. As the hold of the neo-liberal paradigm grows deeper within the academy and in society, there is no way forward intellectually or politically in transforming the violence of racism and imperialism except through Fanon.

\section{About the author}

Sunera Thobani is an Associate Professor at the Institute for Gender, Race, Sexuality and Social Justice at the University of British Columbia. Her book, Exalted Subjects: Studies in the Making of Race and Nation in Canada, was published by the University of Toronto Press (2007), and her current research focuses on Gender, Race, Globalization, Migration and Media Representations of the War on Terror. Sunera is also past president of the National Action 
Committee on the Status of Women (NAC), Canada's then largest feminist organization (1993-1996). The first woman of colour to serve in this position, Sunera's tenure was committed to making the politics of anti-racism central to the women's movement.

\section{References}

Cherki, Alice 2000. Frantz Fanon: A Portrait (translated by Nadia Benabid). Ithaca and London: Cornell University Press.

Fanon, Frantz 1967. The Wretched of the Earth. New York: Grove Press.

Iton, Richard 2008. In Search of the Black Fantastic: Politics and Popular Culture in the Post-Civil War Era. Oxford and New York: Oxford University Press.

Johnson, Linton Kwesi 2002. "Five nights of bleeding", in Mi Revalueshanary Fren: Selected Poems. London: Penguin Books.

Lynd, Staughton 2010. From Here to There: The Staughton Lynd Reader. Oakland, CA: PM Press.

Mignolo, Walter 2013. "Yes We Can: Non-European Thinkers and Philosophers". Al-Jazeera 19 February 2013, online at http://www.aljazeera.com/indepth/opinion/2013/02/20132672747320891.ht $\mathrm{ml}$

Williams, Randall 2010. The Divided World: Human Rights and Its Violence. Minneapolis, MN: University of Minnesota Press. 